Dr NENAD Ž. PETROVIĆ, naučni saradnik

Institut za strategijska istraživanja

Beograd, Neznanog junaka 38

npetrovic21@yahoo.com

94:327(497.1:560)"1980/1983"(093.2)

originalan naučni rad

32:929 Балкар Г.(093.2)

primljeno: 17. mart 2016.

prihvaćeno: 8. februar 2017 .

\title{
UBISTVO TURSKOG AMBASADORA U BEOGRADU 1983. GODINE I JUGOSLOVENSKO-TURSKI ODNOSI
}

APSTRAKT: Članak na osnovu sudskih materijala kao i dokumenata iz Arhive Saveznog sekretarijata za inostrane poslove SFRJ istražuje ubistvo turskog ambasadora u Beogradu Galipa Balkara 1983. godine. Na temelju diplomatskih izveštaja pokušava se sagledati politička pozadina ovog terorističkog akta kao i reperkusije po odnose Jugoslavije sa Turskom koji su tada bili dobri bez obzira na različito društveno-političko i ekonomsko uređenje. Događaj treba posmatrati u kontekstu „poznog doba Hladnog rata "i rivaliteta dva tadašnja bloka.

KLJUČNE REČI: Međunarodni terorizam, Hladni rat, paravojne organizacije, Jermeni, Jugoslavija, Turska

Godina 1980. bila je važna kako za SFRJ tako i za Tursku. Preminuo je Josip Broz Tito a u Turskoj je posle višegodišnje ekonomske i političke krize praćene svakodnevnim terorizmom i haosom u pojedinim regionima vojska izvršila puč i raspustila Skupštinu, smenila Vladu i zabranila rad političkim strankama. Na čelo zemlje došli su generali predvođeni Kenanom Evrenom sa ciljem da zemlji povrate red $\mathrm{i}$ mir. Obe države prolazile su kroz krizu, svaka na svoj način. Iako se činilo da je gotovo pred kolapsom Turska je kao država opstala, dok je tadašnja jugoslovenska kriza koja je u odnosu na tursku izgledala blaga devedesetih godina eskalirala u rat $i$ raspad. ${ }^{1}$ Deo turske štampe, bez obzira na preovladavajući ton uvažavanja i prijatelj-

${ }^{1}$ O ovome piše Nenad Ž. Petrović, „Jugoslovensko-turski vojni i politički odnosi 1980-1982“, Istorija 20. veka, br. 1, (2014), 193-208. O političkim i drugim odnosima Jugoslavije sa Turskom posle 1945. godine malo je pisano: „Tursko-jugoslovenski odnosi“, u: Enciklopedija Jugoslavije, 8 (Zagreb: Jugoslavenski leksikografski zavod, 1971) 1, 397-398; „Turska“, u: Vojna enciklopedija, 10 (Beograd: Vojnoistorijski institut, 1975) $)^{2}$, 185; Balkanski pakt 1953/1954, zbornik dokumenata, redakcija Milan Terzić i dr., (Beograd: Vojnoistorijski institut, 2005); Balkanski pakt 1953/1954, zbornik radova, urednik Nemanja Milošević (Beograd: Institut za strategijska istraživanja Odeljenje za vojnu istoriju, 2008). Sporadično se podaci mogu naći u delima koja obrađuju spoljnu politiku SFRJ prema Zapadu: Dragan Bogetić, Jugoslavija i Zapad 1952-1955: Jugoslovensko približavanje NATO-u (Beograd: Službeni list SRJ, 2000); Isti, Nova strategija jugoslovenske spoljne politike 1956-1961 (Beograd: Institut za savremenu istoriju (ISI), 2006); Isti, Jugoslovensko-američki odnosi 1961-1971 (Beograd: ISI, 2012); 
stva i bez obzira na duboke razlike u društvenom, ekonomskom i političkom uređenju kao i na oštru cenzuru u vreme vojne hunte, povremeno je prikazivao SFRJ kao zemlju u kojoj nisu rešeni nacionalni problemi, ističući Kosovo kao primer. ${ }^{2}$

Početkom 80-ih godina, gotovo sinhrono, zamenjeni su ambasadori dve zemlje. Na položaj turskog ambasadora u Beogradu umesto Hikmeta Ozkana došao je Galip Balkar. ${ }^{3}$

\section{Atentat i proces}

Devetog marta 1983. oko 11,10 časova na raskrsnici tadašnje Ulice generala Ždanova i Bulevara revolucije (danas Resavska i Bulevar kralja Aleksandra Obrenovića) dogodilo se političko ubistvo kakvo se do tada nije desilo u Beogradu i čitavoj Jugoslaviji. U klasičnom aktu terorizma, kako je odmah bio okvalifikovan od doma-

Ratomir Milikić, „Nekoliko pitanja jugoslovensko-turske saradnje“, u: Spoljna politika Jugoslavije 1950-1961, zbornik radova, urednik Slobodan Selinić (Beograd: Institut za noviju istoriju Srbije (INIS), 2008), 617-627.

${ }^{2}$ Diplomatski arhiv Ministarstva spoljnih poslova Srbije (DA MSP), Politička arhiva (PA), Turska, 1982, fascikla (f.) 113, dosije (d.) 1, 448133/12.10, Ambasada SFRJ Ankara. Turska strana je imala primedbe na izveštavanje jugoslovenskih medija. Tako je ambasador Balkar zatraživši prijem u SSIP-u preneo načelniku Prve uprave Iliji Đukiću 20. jula 1982. nezadovoljstvo Ankare emisijom prikazanom na TV Beograd 6. jula koja se bavila Sovjetskom Jermenijom. U reportaži je pominjan i genocid izvršen nad Jermenima u Turskoj 1915. godine i navodila se brojka od 1,5 miliona žrtava. Balkar je istakao da do tada u Jugoslaviji nije bilo takvih emisija, a da „turski naučnici pokušavaju objasniti i javno objaviti naučne radove o zbivanjima iz tog vremena“; takvo pristupanje problemu „moglo bi i od Jugoslavije vremenom stvoriti plodno tle za terorističke akcije Jermena uperene protiv turskih diplomatskih predstavnika u svetu“. Đukić mu je odgovorio da su u Jugoslaviji novinari slobodni u svom radu i da jedna emisija ne može predstavljati predtekst za terorizam protiv Turske. (Isto, d. 10, 436091/22.7, Savezni sekretarijat za inostrane poslove, Prva uprava. Zabeleška o razgovoru).

${ }^{3}$ O tome videti: traženje agremana za Balkara (DA MSP, PA, Turska, 1981, f. 123, d. 9, pov. br. 424440); oproštajni razgovori Ozkana sa Dobrivojem Vidićem predsednikom Predsedništva SR Srbije (Isto, pov. br. 435659), sa Miloradom Pešićem zamenikom saveznog sekretara za inostrane poslove (Isto, pov. br. 435941) i sa Dragoslavom Markovićem, predsednikom Skupštine SFRJ (Isto, pov. br. 437510). Počev od 1973. kada su se aktivirale jermenske nacionalističke i osvetničke organizacije izvršen je veliki broj atentata na turske predstavnike u svetu. O tome videti spisak atentata izvršenih od januara 1973. do oktobra 1981. prema kojem je evidentirano ukupno 56 napada u 15 država. Najviše ih je bilo u Francuskoj - 14, potom u Italiji - 8, Švajcarskoj - 7, u SAD - 5. (Isto, 1982, f. 113, d. 6, 413748/17.3, Ambasada SFRJ Ankara). Docnije, tokom 1982. godine jermenski borci izvršili su prvi, ali spektakularan napad u samoj Turskoj: 7. avgusta u holu ankarskog aerodroma Esenboga pucali su i bacali ručne bombe na prisutne ubivši 9 a ranivši 72 osobe. Od ubijenih petoro su bili građani, dvojica policajci, šef policijske ispostave i pomoćnik direktora aerodroma. Jedan atentator je ubijen na mestu, a drugi je ranjen i uhapšen (Isto, 438963/10.8, Ambasada SFRJ Ankara). Jermenske organizacije su se obraćale jugoslovenskim diplomatsko-konzularnim predstavnicima u svetu. O tome svedoči dopis Generalnog konzulata SFRJ iz Toronta od 12. avgusta 1981. kojim SSIP-u dostavlja pismo na engleskom jeziku koje je konzulat primio od Jermenske revolucionarne federacije - Omladinske organizacije u Kanadi. U pismu se iznose njeni ciljevi uspostava nezavisne Jermenije kako je bilo predviđeno mirovnim ugovorom u Sevru od 10. avgusta 1920. potpisanom između sila Antante i Otomanske imperije. Jermenska organizacija je dostavila i fotokopiju štampanog ugovora iz Sevra na engleskom jeziku (ovaj mirovni ugovor je jedini od potpisanih posle Prvog svetskog rata koji nije stupio na snagu a revidiran je 1923. godine ugovorom u Lozani). Među potpisnicima ugovora bili su Nikola Pašić i Ante Trumbić kao predstavnici Kraljevine Srba, Hrvata i Slovenaca na mirovnoj konferenciji. U pismu jermenske organizacije naglašavalo se da je SFRJ pravni sledbenik Kraljevine SHS te joj se stoga obraćaju (Isto, 1981, f. 122, d. 9, pov. br. 444960). 
ćih faktora, ubijen je ambasador Republike Turske Galip Balkar. Ubistvo su izvršili prema prethodnom dogovoru i posle opsežnih priprema dvojica mladih Jermena državljana Libana: Harutioni Levonijan (Haroutiony Levonian) rođen 1956. i Rafi Elbekian (Raffi Elbakain) rođen 1962. godine. Tokom istrage prvooptuženi Levonijan priznao je da mu je pravo ime Antrani Bogosian (Antrani Boghossian), jer je radi dobijanja državljanstva čitava njegova porodica u svoje vreme preuzela identitet članova familije za koju su znali da se iselila iz Libana a svoja dokumenta su prijavili kao uništena. Ipak, kako u presudi stoji ime iz pasoša to ćemo ga koristiti u članku.

Crni mercedes sa diplomatskim oznakama koje su upućivale da je u njima ambasador (oznaka 01) i sa turskom zastavicom na prednjoj haubi stao je ispred semafora čekajući zeleno svetlo. U trenutku dok se vozilo zaustavljalo dvojica atentatora prišli su kolima. Prvooptuženi Levonijan je bio zadužen da ubije ambasadora koji se nalazio na zadnjem desnom sedištu. Levonijan je stajao na trotoaru ispred tadašnjeg „Tehnoprometa“. Drugi atentator Elbekijan nalazio se na suprotnom trotoaru ispred tadašnjeg bifea Mala Madera (sada Kantina food) i bio je zadužen da neutrališe vozača. Istovremeno, obojica su otvorili vatru iz pištolja "duge devetke“. Levonijan je ispalio četiri metka u Balkara nanevši mu teške rane po glavi i u ramenu, dok je Elbekijan ispalio samo jedan metak kojim je ranio vozača u rame. Vozač Nedžati Kaja imao je revolver „magnum“ na dohvat ruke koji nije upotrebio, kako je kasnije izjavio, jer nije bio vičan i zato što se bojao da će ugroziti prolaznike. Vozač se posle prvog hica sklupčao iza volana u strahu za život. Sve se odigralo u nekoliko sekundi dok je kolona vozila u sve tri trake stajala na crvenom svetlu. Ustrelivši Balkara, Levonijan je u panici propustio da iz torbice koju je nosio izvuče belo platno sa ispisanim akronimom JCAG (Justice Commando for Armenian Genocide - Izvršioci pravde za Jermenski genocid) i da ga prebaci preko auta, što je bilo u planu. On se odmah okrenuo i potrčao.

Šta se dešavalo u narednih minut-dva ne može se jednostavno rekonstruisati, iako osim saslušanja atentatora postoje i brojni iskazi svedoka: Levonijan je već na prvom koraku naleteo na domaćicu Zoricu Zolotić koja mu se isprečila pa je ispalio hitac koji je srećom samo okrznuo njenu glavu. (Odbrana optuženog u procesu će pokušavati da dokaže da Levonijan nije ispalio ovaj hitac.) Čim su se začuli prvi pucnji prisutni na raskršću su obratili pažnju na događaj, začuli su se uzbuđeni povici: „Ubiše čoveka! Držite ubicu!!!“ i slično. Iz lokala su izletali prodavci a na prozorima su se pojavili brojni znatiželjnici. Levonijan je od mesta zločina pretrčao još tridesetak metara Bulevarom usput odgurujući prolaznike koji su mu se što svojevoljno što slučajno isprečili. Ispred ulaza u broj 34 naleteo je na pukovnika JNA u penziji Slobodana Brajovića (1924) kome je poslednje radno mesto bilo načelnik Vojnoizdavačkog zavoda. On je šetao svog unuka pa je odgurnuo dete u stranu i raširivši ruke obuhvatio Levonijana oko pojasa dok je ovaj protrčavao mimo njega, a prolaznik Milivoje Nikolić je atentatora ščepao za levu ruku u kojoj je ovaj držao pištolj. Levonijan je uspeo da istrgne ruku i ispali hitac u Brajovića sa kojim se još uvek gušao i nanese mu tešku ranu od koje je ostao oduzet u donjem delu tela. Potom je pretrčao preko kolovoza i ušao u Tašmajdanski park na mestu gde tramvajske šine zaokreću prema početnoj stanici tramvaja ,̌sestice“. U tom trenutku hitac ispaljen iz pravca poslovnice JAT-a (danas Air Serbia) pogađa Levonijana koji pada licem pre- 
ma asfaltnoj stazi i tom prilikom mu od siline udara biva izbijeno sedam zuba iz gornje vilice koje je od ranije nameštao kao „most“. Iz usta mu kulja krv. Glava mu je položena prema zemlji, povremeno je okreće u stranu i nešto govori. Jedan od svedoka je tvrdio da je na jasnom srpskom rekao: „Neću i ne mogu više.“ Drugi su izjavili da je na engleskom rekao da je Jermenin koji izvršava pravdu... I on je osakaćen tako da je ostao vezan za invalidska kolica jer mu je metak oštetio kičmeni stub. Prikupljaju se radoznalci, gnevni građani sigurno bi ga linčovali šutirajući ga onako ležećeg i bespomoćnog da se nije pojavio civil (kasnije će se ispostaviti da je to pripadnik milicije navodno na odmoru koji se navodno tu slučajno zatekao i koji ga je pogodio iz službenog pištolja). On prisebno papirnom maramicom uzima pištolj koji je ranjenom ispao iz ruke da se ne bi obrisali tragovi i zajedno sa još jednim civilom za koga do kraja istrage nije ustanovljeno ko je, ali po svoj prilici da je i on bio policajac, sprečava prisutne da izvrše linč nad ranjenim teroristom. Pored Levonijana je torbica u kojoj će policija pronaći pasoše za obojicu.

Drugookrivljeni Elbekijan je odmah po ispaljivanju hica u vozača pretrčao raskrsnicu i pojurio kroz park dok ga je ganjala grupa prolaznika. Posle jedinog ispaljenog hica njemu se metak zaglavio u cevi. On je $u$ trku uspeo da odglavi mehanizam i u jednom trenutku se okrenuo i ispalio metak kojim je usmrtio jednog od progonitelja - Željka Milivojevića (1958), studenta Mašinskog fakulteta, iz Inđije. Prema njegovom iskazu iz istrage nameravao je da ispali hitac u zemlju samo radi zastrašivanja progonitelja. (Ovaj detalj ostaće sporan i na njega ćemo kasnije obratiti pažnju jer je odbrana pokušala da dokaže da je Elbekijan ubio Milivojevića nehotice pa čak i da ga je nehotice usmrtio ili onaj milicioner koji je ranio prvooptuženog ili možda onaj drugi koji nikada nije identifikovan. Da je postojao još najmanje jedan pripadnik Gradskog SUP-a u civilu na licu mesta pokazuje činjenica da je dok je prvi obezbeđivao mesto na kojem je ležao Levonijan nepoznato civilno lice ušlo u mercedes ambasade, selo za upravljač i prevezlo teško ranjenog ambasadora u bolnicu na operaciju.) Elbekijan je uhapšen tek oko 19 časova na železničkoj stanici u Novom Sadu odakle je imao nameru da se uputi u Vršac. Istraga se uopšte nije pozabavila pitanjem da li je tamo neko trebalo da ga čeka i obezbedi mu ilegalni prelazak u Rumuniju budući da mu je pasoš ostao kod ranjenog Levonijana. ${ }^{4}$

Na osnovu zapisnika o saslušanju okrivljenih, optužnice i presude moguće je rekonstruisati pripreme i izvršenje atentata ali je nemoguće otkriti ko je bio tajanstveni „treći čovek“ kako ga sam prvooptuženi koji je sa njim komunicirao često naziva. Levonijan je, opisavši na prvom saslušanju sebe kao vlasnika restorana i noćnog lokala od 400 kvadrata u Bejrutu i dobrog imovnog stanja, pokušavao da delo

${ }^{4}$ Istražni i sudski materijali na osnovu kojih smo ukratko opisali atentat i iz kojih ćemo citirati izjave okrivljenih kao i presude dati su nam na uvid iz arhive advokatske kancelarije Popović\&Samardžija. Dokumenti su neregistrovani i nesređeni: Zapisnici o saslušanjima okrivljenog Levonijana od 19. 3., 15. 4., 18. 4. i 3. 9. 1983; Zapisnici o saslušanjima okrivljenog Elbekijana od 12. 3., 15. 3., 17. 3. i 29. 8. 1983; Više izjava očevidaca koje su dali inspektorima GSUP Beograd; Optužnica Okružnog javnog tužioca od 9. 9. 1983. Takođe, o događaju pišemo i na osnovu izveštaja i ekskluzivnih fotografija koje je donela Политика, 10. 3. 1983, 1, 4-5; 11. 3. 1983, 1, 4-5. O atentatu je svedočanstvo ostavio i penzionisani pripadnik policije Slobodan Vujanović, Ubistva i silovanja: iz dnevnika inspektora GSUP-a Beograd (Beograd: Tipo štampa, 2009). 
predstavi kao individualno ne pominjući organizaciju. Navodno je putujući svojim kolima za Belgiju zastao u Beogradu pa je šetajući primetio zgradu sa turskom zastavom. Tada je počeo da razmišlja ,o onome što su Turci učinili nama Jermenima, o onome što smo mi učili u istoriji, što uči svaki mladi Jermenin, odnosno o čemu razmišlja svaki mladi Jermenin, o čemu se ispevaju pesme. ${ }^{65}$ Produžavajući svoju neveštu odbranu Levonijan je ispričao kako je vrativši se kolima u Atinu u jednom kabareu kupio pištolje od nepoznatih ljudi, da ih je u kolima preneo u Beograd i tu sakrio ispod sedišta $\mathrm{u}$,,jednom disko klubu koji se nalazi u jednom podrumu preko puta hotela Moskve“. ${ }^{6}$ Na pitanje istražnog sudije da li je još neko osim njih dvojice učestvovao u organizaciji ubistva najpre je odgovarao odrečno. Na kasnijim saslušanjima osumnjičeni je otkrio da mu je oružje i novac za izvršenje dela obezbedio misteriozni „treći čovek“7 ${ }^{\text {sa kojim se sastajao u kafeu hotela Moskva. }}{ }^{8}$

Drugoosumnjičeni Elbekijan takođe je na prvim saslušanjima nevešto izbegavao istinu prikazujući sebe kao žrtvu Levonijana koji ga je poveo u Istočnu Evropu da se provedu pa mu je neposredno pred atentat otkrio pravi cilj. Zapravo, kako je kasnije priznao, i on je bio član jermenske organizacije i još u Bejrutu je došlo do dogovora da izvrše atentat. Avionom su iz libanske prestonice doputovali u Atinu, a odatle su drugim letom stigli u Budimpeštu. Iz mađarske prestonice su vozom prispeli u Novi Sad za koji su se iz bezbednosnih razloga odlučili da im bude baza jer tamo za razliku od Beograda nisu zadržavali pasoše na recepciji hotela. Nekoliko dana uoči atentata oni su svakog jutra autobusom putovali u Beograd i osmatrali tursku ambasadu i okolne ulice, a Levonijan se sastajao sa neznancem. Dan pre ubistva, 8 . marta, „treći čovek“ mu je predao dva pištolja španske proizvodnje modela STAR kalibra „duga devetka“. U vreme atentata organizator se nalazio kod poslovnice JATa nadgledajući događaj. Nakon toga on je po svoj prilici svojim automobilom marke BMW nemačkih oznaka napustio Jugoslaviju. Verovatno da je on u kolima i preneo oružje do Beograda. ${ }^{9}$

${ }^{5}$ Iz saslušanja obojice stiče se utisak da su Jermeni u čitavom svetu samoizolovana zajednica koja se nerado meša sa domaćinima, da vaspitavaju mlade naraštaje u duhu mržnje i odmazde nad Turskom i Turcima, da su izuzetno solidarni i da svaki mladić i devojka od 16 do 23 godine mora pripadati skautskoj organizaciji koja je neka vrsta predvojničke obuke praćena političko-nacionalnom indoktrinacijom.

${ }^{6}$ Prema opisu to bi mogao biti tadašnji restoran Romanitar koji se nalazio u podrumu današnjeg McDonald's restorana na Terazijama. Kao što ćemo videti ovo je bila krajnje naivna priča koja pokazuje mentalni sklop takvih ,ubica iz idealnih pobuda“ bez obzira na njihove političke ciljeve - izvanredna mešavina fanatičnosti i dečija struktura providnih laži.

${ }^{7}$ Povremeno ga okrivljeni u zapisnicima naziva Samil, ali to mu sigurno nije pravo ime. Opisuje ga kao tipičnog orijentalca: visine 170 centimetara, punog tela, sa crnim brkovima.

${ }^{8}$ Arhiva advokatske kancelarije..., Zapisnici o saslušanjima od 19. marta i 15. aprila 1983. Zbog kritičnog stanja u kojem je primljen Levonijan je prvi put saslušan tek 19. marta i to, po savetu lekara, kratko.

${ }^{9}$ Isto, Zapisnici o saslušanjima od 12, 15. i 17. marta i od 29. avgusta 1983. Elbekijan je izjavio da je prva tri dana u zatvoru, koja je prema ondašnjim propisima proveo u rukama policije, bio batinan ali od trenutka kada je prešao u nadležnost istražnog sudije nije se mogao požaliti. Ovo izgleda da je bilo više odmazda za ubistvo Milivojevića nego što je bilo u funkciji njegovog priznanja jer izvršioci nisu negirali učinjeno delo. Oba atentatora naglašavala su da im nije bio cilj da ubiju nijednog jugoslovenskog građanina, da veoma poštuju Jugoslaviju, da nisu imali nameru ni vozača da ubiju jer to ne bi imalo svrhe, već samo predstavnika vlade koja neće da prizna genocid $i$ dâ zadovoljenje žrtvama. Posebno se Elbekijan gorko kajao zbog ubistva Milivojevića. Ni jedan ni drugi nisu iskazivali kajanje zbog ubistva Balkara. 
Prvostepenom presudom izrečenom 9. marta 1984. Levonijan i Elbekijan su osuđeni svaki na po 20 godina zatvora i trajno progonstvo iz Jugoslavije po izdržanoj kazni. Prvooptuženom je kod odmeravanja kazne uzeto u obzir trajno osakaćenje zbog kojeg ne bi ni mogla da bude izvršena smrtna kazna (prema zakonu smrtna kazna se nije mogla izvršiti nad nemoćnim i teško obolelim licima), a za drugooptuženog Elbekijana razlozi za neizricanje smrtne kazne ležali su u tome što je u trenutku izvršenja dela bio tzv. mlađi punoletnik (osoba koja je navršila 18 godina ali još nije napunila 21 godinu). Sud mu je kao olakšavajuću okolnost priznao i to što je psihijatrijskim veštačenjem utvrđeno da je emocionalno nezrela ličnost, labilne $i$ egocentrične afektivnosti te da je bio puki izvršilac volje prvookrivljenog. ${ }^{10}$ Po žalbi osuđenih $\mathrm{i}$ njihovih branilaca veće Vrhovnog suda SR Srbije zasedalo je i 3. oktobra 1984. donelo izvršnu presudu kojom je potvrdilo kaznu Levonijanu a Elbekijanu je ublažilo na 15 godina zatvora. Potvrđujući kaznu prvooptuženom sud je našao da je on počinio jedno od najteže kažnjivih krivičnih dela te da je režiser i izvršilac ove akcije. ${ }^{11}$

Krupna materijalna greška koja se potkrala u zapisniku o obdukciji mogla je ozbiljno da uzdrma optužnicu za ubistvo studenta Milivojevića i time u toj tački rastereti jednog od atentatora. Naime, sudski obducent dr Snežana Veljković koja je uradila obdukcija unela je u protokol da je projektil izvađen iz mrtvog Milivojevića prečnika 7 milimetara. Advokat Srđa Popović u svojoj žalbi Vrhovnom sudu pokušavao je da dokaže kako je to pokazatelj da je milicioner koji je pre toga teško ranio Levionijana a svakako u nameri da spreči bekstvo i drugog atentatora - promašio svoj cilj i slučajno usmrtio Milivojevića. Naime, Popović je isticao da ne postoji kalibar 7 milimetara ali postoji 7,65 milimetara a takav je upravo pištolj Crvena zastava iz naoružanja milicije. Obojica atentatora imala su kalibre od 9 milimetara. Popović je insistirao da je nemoguće da je tolika greška mogla nastati od strane obducenta, a da je pogotovu neverovatno objašnjenje kako je prilikom kucanja izveštaja daktilograf pogrešio. Takođe je dovodio u sumnju nalaze dvojice veštaka - kriminalističkih tehničara Gradskog SUPa koji su bez pisanog naloga istražnog sudije izvršili balističko veštačenje na pronađenim čaurama na raskršću i u parku. Pozivao se na slovo zakona po kome sve istražne radnje bivaju po pisanom nalogu istražnog tužioca i u njegovom prisustvu. Ovim je odbrana insinuirala da su dva kriminologa svojim nalazima pokrivali nehotično ubistvo koje je izvršio njihov kolega. Sud je ove primedbe odbacio, našavši kako je nedvosmisleno utvrđeno da je Milivojevića upucao Elbekijan. Grešku u izveštaju obducenta sud je objasnio time da medicinar može da pogreši kod merenja promera rane jer on za to nije dovoljno stručan te da se merenje stručnjaka balističara mora uzeti kao pouzdanije: „Ako se pošlo od pretpostavke da je obducent pogrešno izmerio prečnik projektila ili upisao pogrešno $7 \mathrm{~mm}$ umesto $7,65 \mathrm{~mm}$ takvom prečniku nikako ne bi odgovarala dužina projektila od $15 \mathrm{~mm}$ što je obducent takođe konstatovao, jer je to skoro istovetna dužina 'duge devetke', a projektil 7,65 mm kako je objasnio veštak, dužine je $11,7 \mathrm{~mm}$.“12

\footnotetext{
${ }^{10}$ Isto, Presuda Okružnog suda u Beogradu, K-533/83.

${ }^{11}$ Isto, Presuda Vrhovnog suda Srbije, Kž. I 700/84.

${ }^{12}$ Isto, str. 14. O atentatu, ali ne i o grešci, govori se u: Snežana Veljković, Hronika sudske medicine u Beogradu, istorijat, ljudi i događaji 1863-1923-2008 (Beograd: Medicinski fakultet, 2009), 273-274.
} 
Poslednji od argumenata odbrane bio je politički i za njega je bio zadužen advokat Veljko Guberina koji je u opširnoj žalbi Vrhovnom sudu elaborirao problem nastao sa zločinima prema Jermenima tokom Prvog svetskog rata. Pozivajući se na neke podatke i autore on je izneo tragično stradanje ovog naroda 1915. godine, čime je želeo da ukaže na političku dimenziju atentata i taj način ublaži odgovornost optuženih. Sud je, međutim, slično kao i tužilac odbio da se u vezi sa tim upušta u diskusiju: „I po oceni Vrhovnog suda Srbije nije bilo nužno izvoditi i dokaze predlagane tokom postupka i žalbama, kojim bi se, po stavu žalilaca, dokazala stradanja Jermena i nepravde koje su im kroz istoriju činjene i koje se čine, budući da je bitno subjektivno uverenje optuženih u vezi tih okolnosti. Nema sumnje da optuženi duboko veruju u istorijsku prošlost svog naroda te kako im se na teret ne stavlja krivično delo vezano za motiv, koji bi bio obeležje dela, suvišno bi bilo posebno utvrđivati i te činjenice." ${ }^{\text {13 }}$ Ovo bi prevedeno sa komplikovanog sudskog jezika na običan glasilo: za procenu učinjenog dela bitno je šta su atentatori osećali kada su se odlučili na ubistvo a ne šta je zaista bilo 1915. godine. Stoga je bespredmetno upuštati se u istorijska razmatranja za šta sud nije ni pozvan niti stručan. Samo nekoliko godina po osudi dvojica atentatora su pomilovani odlukom Predsedništva SFRJ i proterani zauvek iz Jugoslavije.

\section{Diplomatska arhiva o atentatu}

Na dan atentata državni vrh predvođen predsednikom Predsedništva SFRJ Petrom Stambolićem i saveznim sekretarom za inostrane poslove Lazarom Mojsovim nalazio se u Nju Delhiju gde je prisustvovao Sedmoj konferenciji nesvrstanih zemalja. Odmah po saznanju za zločin upućena im je poverljiva depeša preko ambasade u Nju Delhiju u kojoj se obaveštavalo o događaju. ${ }^{14}$ Sutradan, iz zgrade u ulici Kneza Miloša upućen je novi telegram „drugu Stamboliću lično“ u kojem ga izveštavaju da su Lazar Koliševski (član Predsedništva) i „ostali drugovi“ predložili da se Željku Milivojeviću i Slobodanu Brajoviću dodele ordeni Narodnog heroja „da bi se time istakla podrška opštenarodnoj odbrani i društvenoj samozaštiti.“ Depešu je potpisao Mika Špiljak, član Predsedništva. ${ }^{15}$ U Ankari je samo nekoliko sati nakon atentata jugoslovenski ambasador Redžep Džiha pozvan kod ministra inostranih poslova Turkmena. Domaćin mu je preneo puno poverenje u jugoslovenske organe i pošto je

${ }^{13}$ Arhiva advokatske kancelarije..., Presuda Vrhovnog suda Srbije, Kž. I 700/84, str. 16.

${ }^{14}$ DA MSP, PA, Turska, 1983, f. 108, d. 9, pov. br. 49044/9.3, Savezni sekretarijat za inostrane poslove. U kratkom saopštenju se navodi da je jedan od dvojice atentatora teško ranjen u pucnjavi ,sa našom patrolom milicije“. Ovo pokazuje da se milicioner koji je upucao Levonijana nije slučajno našao na mestu zločina, kako je kasnije zvanično prikazivano.

${ }^{15}$ Isto, pov. br. 49046/10.3, Savezni sekretarijat za inostrane poslove. Ukazom Predsedništva SFRJ posthumno će biti odlikovani Balkar Ordenom jugoslovenske zastave sa lentom, Milivojević Ordenom zasluga za narod sa zlatnom zvezdom dok je Brajović odlikovan Ordenom jugoslovenske zvezde sa lentom. Neimenovani pripadnik milicije odlikovan je Ordenom za hrabrost (Kabinet ordena, br. $19 \mathrm{uz}$ akt 1727 u DA MSP, PA, Turska, 1983, f. 108, d. 29; Политика, 18. 3. 1983, 1). Republika Turska odlikovala je Milivojevića i Brajovića Zlatnim medaljama časti sa lentom, a pripadnika milicije koji je ranio Levonijana Medaljom za hrabrost (Политика, 23. 3. 1983, 1; DA MSP, PA, Turska, 1983, f. 108, d. 10, pov. br. 411289/22.3, Savezni sekretarijat za inostrane poslove). 
obavešten da je jedan od atentatora uhapšen zamolio je da bude obaveštavan o njegovom identitetu i o onome što će izjaviti na saslušanjima. Još je ,upitao da li mogu u Jugosl. poslati nekog koji bi eventualno pružio pomoć našim islednim organima.“ Jugoslovenski diplomata mu je u ime vlade i u svoje ime izrazio „ogorčenje i najdublje žaljenje“. Posle upoznavanja sagovornika sa činjenicom o žrtvama među jugoslovenskim građanima koji su pokušali da uhvate atentatore, Turkmen je takvo ponašanje primio sa simpatijom. ${ }^{16} \mathrm{Na}$ traženje turske strane Savezni sekretarijat za unutrašnje poslove dao je saglasnost da jedan stručnjak iz turske policije doputuje radi saradnje sa jugoslovenskim islednim organima. ${ }^{17}$

Politika od 10. marta 1983. donela je osvrt ,Teroristički akt“ iz pera svog spoljnopolitičkog komentatora Boška Jakšića, koji se može smatrati za odraz zvaničnog stava države. Suština teksta jeste da je Jugoslavija uvek osuđivala svaki terorizam i namirivanje istorijskih računica na takav način. Nikakva opravdanja se ne mogu tražiti za ovaj čin. Ipak u narednim danima, kao mogući balans, isti novinar dao je u nastavcima istorijat ovog problema trudeći se da ostane distanciran i bez prejudiciranja. Agencija Frans pres saopštila je da je primila poruku organizacije Komandosi izvršitelji pravde za genocid nad Jermenima koja je preuzela odgovornost za atentat. ${ }^{18}$

Uprkos velikom trudu hirurga VMA ambasador Balkar preminuo je 11. marta. Sačuvan je dopis SSIP-a upućen dežurnom istražnom sudiji kojim se prenosi zahtev turske vlade ,a u saglasnosti sa saveznim sekretarom za unutrašnje poslove, S. Dolancom (...) da se ne izvrši obdukcija leša ubijenog (...) Napominjemo da postoji naš interes da se ovom zahtevu Turske udovolji i da bi u suprotnom proizašle neželjene posledice za jugoslovensko-turske odnose i našu zemlju." U poslednjem pasusu istražni sudija se stavljao pred svršen čin rečima da je već saopšteno turskoj ambasadi da će njihovom zahtevu biti udovoljeno. ${ }^{19}$

Sredstva informisanja u Turskoj su opširno izveštavala o atentatu. Prvi pregled medija poslat je iz Ankare 11. marta: štampa je detaljno opisala atentat i pohvalila hrabro i odlučno držanje Jugoslovena. List Terdžuman je svoj komentar naslovio „Bravo Jugosloveni“. Veći broj turskih građana javljao se telefonom ambasadi izražavajući zahvalnost i simpatije Jugoslaviji, njenoj Vladi i narodu. Turski mediji osuđivali su Francusku jer se u njoj blagonaklono gledalo na jermenski terorizam. ${ }^{20} \mathrm{U}$ sledećoj informaciji kaže se da je veliki broj turskih ,,radnika, studenata, đaka, domaćica, biznismena, trgovaca, viših oficira i oficira bezbednosti, funkcionera u privrednoj komori, odeljenja za štampu u parlamentu, udruženje boraca u Koreji, đaci i uči-

${ }^{16}$ DA MSP, PA, Turska, 1983, f. 108, d. 9, br. 410087/10.3, Ambasada SFRJ Ankara.

${ }^{17}$ Isto, br. 410216-1/10.3, Savezni sekretarijat za inostrane poslove Prva uprava.

${ }^{18}$ Istovetno saopštenje primila je i redakcija atinskog lista АВГН (Avgi), organa Komunističke partije Grčke „unutrašnje“ ili „,za zemlju“ (,evrokomunistička“ levica nasuprot onoj koja je važila za „promoskovsku“). Isto, 410699/11.3, Generalni konzulat SFRJ Solun.

${ }^{19}$ Isto, br. 410337/11.3, Savezni sekretarijat za inostrane poslove. Na ovaj način izvršna vlast se uplela u istražni postupak i onemogućila izvršenje zakonske obaveze da se nad svakim ko je doživeo ili se sumnja da je doživeo nasilnu smrt izvrši obdukcija. Pretpostavljamo da je turski zahtev bio rukovođen verskim običajima koji zabranjuju seciranje leševa.

${ }^{20}$ Isto, br. 410676/11.3, Ambasada SFRJ Ankara. U Francuskoj je i danas najbrojnija i najuticajnija jermenska kolonija u Evropi. U svetu su najbrojnije kolonije Jermena u SAD, potom u Libanu, Kipru i Grčkoj. 
telji iz više turskih gradova“ uputio telefonom ili telegramima poruke divljenja zbog hrabrog ponašanja jugoslovenskih građana, ističući da bi u svetu brzo bio ugušen terorizam kada bi svuda bili tako odlučni i hrabri; divili su se mladom studentu koji je poginuo i zahvaljivali na požrtvovanju pukovnika „hrabre jugoslovenske armije“ kome žele brz oporavak. ${ }^{21}$

Sa atentatom u vezi zanimljiva je službena zabeleška o razgovoru načelnika Uprave za Zapadnu Evropu Vladislava Jovanovića sa prvim sekretarom ambasade Francuske gospođicom F. Burolo (F. Bourolleau) na njen zahtev. Burolo je obavestila sagovornika da je u ponedeljak 7. marta uveče ambasador Balkar svojim privatnim autom BMW došao u njen stan da bi je izveo na večeru. Kada su sišli na ulicu, Balkar je vidno uzbuđen konstatovao da je brava na desnoj strani bila blokirana. Glasno je zaključio da je neko preko vikenda pokušao nasilno da uđe u kola. Sagovornica je izrazila želju da o svemu dâ izjavu i pred istražnim organima ukoliko to bude potrebno. U nastavku razgovora Burolo je potvrdila Jovanoviću ono što je već čuo - da su službenici Francuskog kulturnog centra posle atentata primili više telefonskih pretnji na lošem srpskom jeziku kao i da je ,jedno mlađe lice arapskog izgleda juče pokušalo da uđe u zgradu, ali se posle pitanja koga traži, zbunjeno povuklo.“22

Niz depeša je upozoravao na opasnost da diplomatska i druga predstavništva Jugoslavije postanu meta jermenskih terorističkih organizacija širom sveta, a sve u cilju iznuđivanja oslobađanja dvojice atentatora. Alarmantan je bio dopis ambasade SFRJ iz Bejruta. U njemu stoji upozorenje: „U Bernu su 1980. uhvaćeni jermenski nacionalisti-teroristi kojima je slučajno eksplodirala bomba namenjena turskom diplomatskom predstavništvu u Švajcarskoj. Iako su bili teško ranjeni ovim Jermenima je suđeno. Nakon odbijanja švajcarskih vlasti da na zahtev jermenske terorističke organizacije uhvaćene teroriste puste na slobodu, oktobra 1980. usledio je talas akcija protiv švajcarskih $\mathrm{d} \mathrm{k}^{23} \mathrm{i}$ drugih predstavništava $\mathrm{u}$ inostranstvu. Prema našem znanju: podmetnute su bombe u birou Swissair u Parizu i Brislu, dok je u Švajcarskoj izazvan požar u jednoj fabrici. 8. oktobra 1980. u Bejrutu je podmetnut eksploziv ispred stana švajcarskog ambasadora u Bejrutu, kada je pričinjena velika materijalna šteta u celoj zgradi u kojoj je i naša rezidencija. Posle prošlogodišnjeg atentata Jermena na turskog diplomatu u Švajcarskoj, lokalne vlasti pripremaju suđenje uhvaćenim teroristima uz istovremeno posebno pregovaranje sa jermenskom terorističkom organizacijom. (...) Izgleda da je Francuska pristala da jermenske teroriste oslobodi bez znanja javnosti, uz obavezu j o o ${ }^{24}$ da se atentati protiv turskih predstavnika više

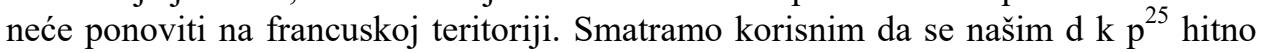
skrene pažnja da preduzmu maksimalne mere bezbednosti (...) Baza jermenskog terorizma je Liban, gde je do skora bilo i sedište tajne j o o, koja je, kako se ovde tvrdi, 1982. prebačena u Nikoziju na Kipru, gde im kiparski Grci pružaju utočište i omogućavaju pripremanje terorističkih akcija. U Libanu postoji brojna jermenska kolonija

${ }^{21}$ Isto, br. 410810/12.3, Ambasada SFRJ Ankara.

${ }^{22}$ DA MSP, PA, Turska, 1983, f. 108, d. 9, pov. br. 410230/10.3, Savezni sekretarijat za inostrane poslove.

${ }^{23}$ Diplomatsko-konzularnih.

${ }^{24}$ Jermenske oslobodilačke organizacije.

${ }^{25}$ Diplomatsko-konzularnim predstavništvima. 
(oko 200 hiljada), čiji su pripadnici stekli sva građanska prava (drže 4 mesta u parlamentu, 1 mesto u vladi i dr.). Iako su libanski državljani, Jermeni se ovde drže podvojeno i zatvoreno su društvo u odnosu na ostale Libance (dve partije, dve verske grupacije, posebne škole i bolnice - sve to samo za Jermene).“26

Prema jednoj depeši iz Rima, jugoslovenski diplomata uspeo je da dokuči domaću „tajnu uspeha“ odnosno kako to da Italija u kojoj takođe ima dosta Jermena (a u ono vreme je bila teren za terorizam s leva i s desna) nije zahvaćena jermenskim aktivnostima. Postignut je, kaže se, dogovor intervenisanjem u tamošnjoj jermenskoj koloniji i preko Vatikana koji posreduje u Moskvi pri dobijanju dozvola za iseljenje Jermena iz SSSR-a koji potom odlaze u SAD i Kanadu, pa su iz zahvalnosti ostavili na miru Italiju. ${ }^{27}$

Jugoslovenska sredstva informisanja, iako su uglavnom bila pod kontrolom vlasti odnosno Saveza komunista i njegovih transmisija (Socijalistički savez radnog naroda, Savez sindikata, Savez socijalističke omladine i dr.), ipak su sve više u raznim prilikama i u raznim povodima a najviše bujanjem nacionalizma počela da otkazuju poslušnost. Osim književne i studentske štampe koja je već u šezdesetim bila u dobroj meri izvan kontrole, početkom osamdesetih dolazilo je do „,iskakanja“ i listova od republičkog značaja. Ipak, vlast je još uvek nalazila načina da utiče na medije i usmerava ih. Informacija Uprave za štampu SSIP-a od 18. marta 1983. govori o tome. U njoj se analizira kako su domaći mediji propratili ispraćaj posmrtnih ostataka Galipa Balkara iz Beograda i svečanu sahranu u Ankari. Mediji su uglavnom korektno ispratili ovaj tužan događaj, ali se konstatuje da su Politika ekspres od 15. marta (na dan sahrane Balkara) kao i Vjesnik od 16. marta dozvolili sebi da uz izveštaje o sahrani donesu spekulacije o tome na koliku kaznu mogu biti osuđeni atentatori. Još dalje je otišao zagrebački nedeljnik Danas koji je 15. marta objavio članak Mihaila Ničote „Zašto ubijaju Turke“ u kojem je autor, prema proceni pisca ove informacije, osim reda radi izrečenih lepih reči o poginulom ambasadoru zapravo iskoristio tekst da opširno piše o jermenskim terorističkim organizacijama u svetu: „U članku, između redova provejava simpatija prema jermenskim teroristima i neka vrsta opravdavanja i objašnjenja da se njihove akcije učine razumljivim.“ Uprava za štampu smatrala je da je ovakvo pisanje štetno i da se u tekstu nigde ne naglašava ono što je bitno - da je atentat bio usmeren protiv dobrih jugoslovensko-turskih odnosa. Autoru se takođe prebacivalo što nije promovisao poznate i načelne jugoslovenske stavove koji osuđuju svaki vid terorizma. U zaključku se kaže da je skrenuta pažnja većini naših redakcija da je neprihvatljivo pridavati veliki publicitet jermenskim terorističkim organizacijama. ${ }^{28}$ Na potrebu snižavanja patetike upozorava depeša iz Pariza. Prenosi se pisanje uticajnog dnevnika Le Monde koji u dopisu iz Ankare sa sahrane Balkara prenosi panegirike turskih zvaničnika upućene najviše Jugoslaviji, potom SAD i Velikoj Britaniji kao zemljama koje pokazuju odlučnost u suzbijanju jermenskog terorizma, dok je izneto žaljenje zbog stava ,jedne savezničke zemlje (...) u kojoj su 1945. godine na desetine hiljada kolaboracionista likvidirani po krat-

\footnotetext{
${ }^{26}$ DA MSP, PA, Turska, 1983, f. 108, d. 9, br. 410198/10.3, Ambasada SFRJ Bejrut.

${ }^{27}$ Isto, d. 10, br. 411818/17.3, Ambasada SFRJ Rim.

${ }^{28}$ Isto, d. 9. br. 410454.
} 
kom postupku, ali koja ni izdaleka nije odustala od pretenzija da bude središte kulture i civilizacije istovremeno nalazeći dovoljno opravdanja za jermenski terorizam. "U zaključku dopisa SSIP-u isticalo se kako je Jugoslavija maksimalno učinila u pokazivanju svog stava prema terorizmu, da bi svako dalje intenzivno pisanje o atentatu na Balkara moglo ,nametnuti utisak našeg bezrezervnog prijateljstva sa aktuelnim režimom, u situaciji kada ga svet, zapad naročito, osuđuje za diktaturu. ‘29

\section{Moguća međunarodna pozadina atentata}

Sa stanovišta moguće uklopljenosti jermenskog terorizma u pozno doba hladnoratovskog nadmetanja korisni su i pojedini dokumenti SSIP-a. Savezni sekretar Lazar Mojsov je na kolegijumu održanom 15. marta, odmah posle povratka sa Konferencije nesvrstanih, obavestio prisutne da je jugoslovenska Služba bezbednosti došla do saznanja „o specijalnoj terorističkoj organizaciji Jermena, koja nam daju uvid u to kako je međunarodni terorizam organizovan. (...) Izneo je da nije slučajno, možda, da su atentatori došli iz Mađarske, a imali kupljene karte za voz za odlazak u Rumuniju.“ Mojsov je obavestio da su osim dvojice neposrednih izvršilaca , uhapšena još neka lica u vezi s ovim atentatom. " (kurziv - N. P.) ${ }^{30}$

$\mathrm{Na}$ dan ispraćaja posmrtnih ostataka turskog ambasadora iz Beograda na drugom programu Moskovske televizije kao i na Ukrajinskoj televiziji davao se sovjetski film „Hlapci vojne muzike“ o Jermenskoj revolucionarnoj omladini koja je 1920. godine zagovarala rešenje jermenskog nacionalnog pitanja oslanjanjem na boljševike. Film je snimljen 1960. godine „, teško je poverovati da se radi o koincidenciji vremena prikazivanja filma i događaja u Beogradu“. Na kraju depeše Generalnog konzulata SFRJ iz Kijeva kaže se da u SSSR-u komentara na atentat nema jer javnost nije obaveštena o njemu. ${ }^{31}$

U depeši ambasade SFRJ iz Beča od 18. marta preneto je obaveštenje tamošnjeg turskog ambasadora. Po Tursku je najopasnija jermenska zajednica u Libanu iz koje se regrutuju teroristi a obučava ih uglavnom Palestinska oslobodilačka organizacija (PLO). Posebnu ulogu u stvaranju klime revanšizma igra Jermenska crkva koja je povezana sa Jermenijom a time i sa SSSR-om. Decenijama nije bilo odmazdi za događaje iz 1915. godine, ali su se jermenske organizacije pokrenule početkom sedamdesetih godina. ${ }^{32}$

U dopisima jugoslovenskih diplomatsko-konzularnih predstavništava iz Atine i Soluna govorilo se da Grčka takođe postaje jedan od punktova jermenskih organizacija nakon izraelske agresije na Liban izvršene 1982. godine. ${ }^{33} \mathrm{U}$ izveštaju ambasade SFRJ u Rimu od 11. marta prenose se ocene tamošnjeg MIP-a o tome zašto je Beograd izabran za mesto atentata $\mathrm{i}$ baš u to vreme. To je učinjeno zbog: istovreme-

${ }^{29}$ Isto, d. 10, br. 411815/17.3, Ambasada SFRJ Pariz.

${ }^{30}$ Isto, d. 9, br. 49066. Ostaće enigma ko su bila ova lica budući da su se na procesu pojavila samo dvojica atentatora.

${ }^{31}$ Isto, d. 10, br. 411499.

${ }^{32}$ Isto, br. 411803.

${ }^{33}$ Isto, d. 9, br. 410681/11.3, Ambasada SFRJ Atina. Br. 410699/ Generalni konzulat SFRJ Solun. 
nog održavanja samita nesvrstanih zemalja čiji je Jugoslavija bila predvodnik pa je procenjeno da će atentat u njenom glavnom gradu privući više pažnje; nezadovoljstva Jermena jer je šef turske države general Evren posetio 1982. godine Jugoslaviju; vrlo dobrih odnosa dve zemlje. Razlog je mogao biti i nedovoljno obezbeđenje stranih predstavništava u Beogradu i liberalan režim prijema stranih studenata među kojima je bilo dosta sumnjivih sa Bliskog istoka. U Rimu je 1981. godine ubijen turski ambasador pri Vatikanu i to ne slučajno u vreme poboljšanja odnosa Turske sa Svetom stolicom. ${ }^{34}$

Italijanske službe bezbednosti procenjivale su jermenske teroriste kao najopasnije i najefikasnije, te da u tom pogledu stoje ispred irske IRA i baskijske ETA. Prema njihovim podacima glavnina jermenskih terorista stoji pod zaštitom palestinskih grupa, a od povlačenja PLO iz Bejruta posle izraelskog napada stacionirali su se na Kipru i u Grčkoj. Jugoslovenski diplomata je savetovan od tamošnjih faktora da bi Jugoslavija najbolje otklonila opasnost od novih napada jermenskih grupa na svom tlu delovanjem preko PLO koja je veoma uticajna u jermenskoj sredini. ${ }^{35}$

Spomenućemo i jednu sumnju o povezanosti nekih faktora u Beogradu sa teroristima. Supruga turskog ambasadora u Helsinkiju u razgovoru sa tamošnjim jugoslovenskim ambasadorom izrazila je sumnju kako je bilo moguće da su ubice znale da će ambasador toga dana u određeno vreme ići kolima u SSIP i kojim putem. Balkar je stanovao u zgradi poslanstva upravo zbog bezbednosti, kako se ne bi morao svakodnevno voziti od rezidencije do ambasade. Aluzija je bila da je ili neko od jugoslovenskih građana zaposlenih $\mathrm{u}$ ambasadi Turske ili neko iz SSIP-a obavestio atentatore o njegovom kretanju kritičnog dana. ${ }^{36}$

Jermenske organizacije su odmah po atentatu pokrenule široku akciju da bi se dvojica atentatora izbavila iz zatvora. U tom cilju obraćali su se jugoslovenskim diplomatskim predstavništvima u mnogim zemljama. U dobro koordiniranoj akciji na adresu ambasade u Teheranu stiglo je za samo nekoliko dana 130 pisama iste sadržine umnoženih šapirografom a potpisanih od različitih osoba u kojima se molilo za oslobađanje. Pri tom se koristila patetika pozivanja na ,jugoslovensku vekovnu borbu protiv otomanskih osvajača i nacističkih agresora koja je uvek služila kao izvanredan primer narodu koji voli slobodu." Levonijan i Elbekijan su oslikani kao borci za emancipaciju naroda i revolucionari. ${ }^{37}$ Posredstvom ambasade SFRJ u Parizu dostavljeno je Predsedništvu SFRJ, SIV-u, SSIP-u i Predsedništvu SR Srbije pismo na francuskom jeziku poslato od Komiteta za odbranu zatvorenika boraca za jermensku stvar (Comite de defense des prisonniers combattants de la cause Armenienne). Pismo je potpisao blagajnik ove organizacije Karaoglanijan i u njemu se ljubaznim izra-

\footnotetext{
${ }^{34}$ Isto, br. 410818

${ }^{35}$ Isto, d. 10, 411818/17.3, Ambasada SFRJ Rim.
}

${ }^{36}$ Isto, 414794/6.4., Ambasada SFRJ Helsinki. Iz istrage se moglo zaključiti da su atentatori nekoliko dana pre akcije izviđali teren oko ambasade. Primili su oružje od „trećeg čoveka“ 8. marta samo dan pre atentata! Kako su mogli biti sigurni da će 9. marta kola proći upravo tuda gde su prošla? Šta bi se desilo da je na semaforu bilo zeleno svetlo? Teroristi su imali dogovor da pucaju samo ako auto stane. Stoga je osnovano pretpostaviti da je bilo još atentatorskih dvojki raspoređenih na semaforima duž trase kretanja prema SSIP-u.

${ }^{37}$ DA MSP, PA, Turska, 1983, f. 108, d. 10, br. 422691/27.5, Ambasada SFRJ Teheran. 
zima skretala pažnja da je slučaj Levonijana i Elbekijana ne samo krivični već da nosi političku dimenziju. Organizacija kojoj oni pripadaju usmerava svoje aktivnosti isključivo na turske zvaničnike kao predstavnike države koja se cinično negatorski odnosi prema genocidu izvršenom nad Jermenima i suprotstavlja se pravednom rešenju jermenskog pitanja. S tim u vezi izražavalo se žaljenje zbog neželjenih žrtava jugoslovenskih državljana. Vlast u Jugoslaviji se molila da optužene Levonijana i Elbekijana tretira kao borce bez uniformi u problemu u kome jugoslovensko pravosuđe ima težak zadatak da presudi. ${ }^{38}$

Iako je ministar Mojsov na kolegijumu u SSIP-u izjavio da je SDB otkrila kako je organizovan međunarodni terorizam, o tome iz dostupnih dokumenata ništa ne saznajemo. Postoji veliki broj „definicija“ terorizma, ali u praksi ocena zavisi od političkog stava i interesa. Što je za jedne pravedna borba naroda za samoopredeljenje ili za socijalna i politička prava - za druge predstavlja terorizam i ugrožavanje državnog integriteta. ${ }^{39} \mathrm{U}$ svetu su postajale različite terorističke organizacije, sa različitim ciljevima i karakteristikama. Uz to, postojala je umreženost raznih organizacija i njihova koordiniranost na globalnom nivou bez obzira na najsuprotstavljenije ideološke obrasce i ciljeve koje javno zastupaju.

Atentat na ambasadora Galipa Balkara izvršen je u vreme detanta i pripremanja pada socijalističkih režima u Evropi. Činjenica je da raspadom SSSR-a jenjavaju $i$ atentati na turske predstavnike u svetu. Atentat u Beogradu ništa posebno nije značio na unutrašnjem planu u Jugoslaviji i ostaće zabeležen kao jedan od retkih atentata na strane državnike izvršen u toj zemlji posle 1945. godine. I u ovom slučaju misteriozni „treći čovek“ (baš kao u slavnom romanu Grejema Grina i još slavnijoj ekranizaciji) nestaje netragom pošto je ispleo svoju paukovu mrežu zavere i organizovao ubistvo. Pravi nalogodavci u političkim ubistvima ostanu po pravilu nepoznati.

\section{IZVORI I LITERATURA}

- Diplomatski arhiv Ministarstva spoljnih poslova Republike Srbije (DA MSP), Politička arhiva (PA), Turska, 1981, 1982, 1983.

- Arhiva advokatske kancelarije Popović i Samardžija, Beograd, neregistrovana i nesređena građa sudskih spisa vezanih za proces Levonijanu i Elbekijanu.

${ }^{38}$ Isto, d. 11, br. 6960. Uprava SSIP-a za Zapadnu Evropu prosleđuje Predsedništvu SFRJ pismo na francuskom jeziku datirano sa Pariz, 6. decembar 1983: „Au delà de ces cruels événements, l' esprit politique de cette affaire ne peut vous avoir échappé. (...) cette organisation semble situer ses actions dans le cadre exclusif du conflit qui oppose la nation arménienne au gouvernement de la Turquie, en évitant de faire des victimes innocentes. (...) notre comité demande au gouvernement de la République Socialiste Fédérative de la Yougoslavie de traiter les accusés - Levonian et Elbekian - en combattants sans uniforme d'une cause que la justice de Yougoslavie a le defficile devoir de juger." (kurziv - N. P.)

${ }^{39}$ O tome piše Vojin Dimitrijević: Terorizam (Beograd: Radnička štampa, 1982). 
- Balkanski pakt 1953/1954, zbornik dokumenata. Redakcija Milan Terzić, i dr. Beograd: Vojnoistorijski institut, 2005.

\section{Политика (март 1983)}

- Balkanski pakt 1953/1954, zbornik radova. Urednik Nemanja Milošević. Beograd: Institut za strategijska istraživanja, Odeljenje za vojnu istoriju, 2008.

- Bogetić, Dragan. Jugoslavija i Zapad 1952-1955: Jugoslovensko približavanje NATO-u. Beograd: Službeni list SRJ, 2000.

- Bogetić, Dragan. Nova strategija jugoslovenske spoljne politike 1956-1961. Beograd: ISI, 2006.

- Bogetić, Dragan. Jugoslovensko-američki odnosi 1961-1971. Beograd: ISI, 2012.

- Dimitrijević, Vojin. Terorizam. Beograd: Radnička štampa, 1982.

- Milikić, Ratomir. „Nekoliko pitanja jugoslovensko-turske saradnje“. U: Spoljna politika Jugoslavije 1950-1961, zbornik radova. Urednik Slobodan Selinić, 617627. Beograd: INIS, 2008.

- Petrović, Nenad Ž. „Jugoslovensko-turski vojni i politički odnosi 1980-1982“. Istorija 20. veka, br. 1, (2014), 193-208.

- „Turska“. U: Vojna enciklopedija, 10. Beograd: Vojnoistorijski institut, 1975. ${ }^{2} 185$.

- „Tursko-jugoslovenski odnosi“. U: Enciklopedija Jugoslavije, 8. Zagreb: Jugoslavenski leksikografski zavod, 1971. ${ }^{1}$ 397-398.

- Veljković, Snežana. Hronika sudske medicine u Beogradu, istorijat, ljudi i događaji 1863-1923-2008. Beograd: Medicinski fakultet, 2009.

- Vujanović, Slobodan. Ubistva i silovanja: iz dnevnika inspektora GSUP-a Beograd. Beograd: Tipo štampa, 2009.

Nenad Ž. Petrović

\section{THE ASSASSINATION OF TURKISH AMBASSADOR IN BELGRADE IN 1983 AND YUGOSLAV-TURKISH RELATIONS}

\section{Summary}

Based on the Federal Ministry of Foreign Affairs data files, as well as on court records, the article gives an account of the March 9, 1983 assassination carried out by two young Armenian men in Belgrade. The assassination took place as the Turkish ambassador Galip Balkar was going in his car to the Foreign Ministry premises. The investigation failed to discover the main person behind the murder, the alleged third man who had supplied the weapons to the two attackers and who had directed their actions. Being the first of the kind in a socialist country, the episode drew a lot of public attention in Yugoslavia and worldwide. Since it was one in a series of assassinations of Turkish representatives abroad, it duly had the international weight. The assassins received their respective sentences of twenty and fifteen years of imprisonment. Their conviction prompted waves of protests of various Armenian organiza- 
tions, exerting pressure on Yugoslavia to release the convicted men. Finally, after they had spent a few years in prison, SFRY Presidency granted them amnesty, and their expulsion from Yugoslavia followed suit. This particular instance has given the author the grounds to make a judgment about the problem of terrorism in the modern world. In conclusion, as long as different political interests exist, there will be different viewpoints on individual acts of terrorism: for some, they will mean a legitimate battle (national movement or class struggle), while others will consider it an unacceptable violence, evil in itself.

KEYWORDS: International terrorism, the Cold War, paramilitary organizations, the Armenians, Yugoslavia, Turkey

\section{УБИЙСТВО ТУРЕЦКОГО ПОСОЛЬСТВА В БЕЛГРАДЕ В 1983 ГОДУ И ЮГОСЛАВСКО-ТУРЕЦКИ ОТНОШЕНИЯ}

\section{Резюме}

В данной статье, на основании архивных документов Союзного секретариата по иностранным делам и судебных документов, описывается покушение, совершенное двумя армянскими парнями в Белграде 9 марта 1983 года. Тогда был убит турецкий посол Галиб Балкар, направляющийся на автомобиле в МИД. Следствию не удалось установить непосредственного организатора убийства, так называемого «третьего человека», который привез оружие и направлял двух исполнителей покушения. Данное событие получило большой резонанс югославского и мирового сообщества, так как подобное впервые произошло в одной социалистической стране. Оно имело и большое международное значение, так как является одним из ряда покушений на турецких представителей за рубежом. Лица, совершившие покушение, приговорены к двадцати и пятнадцати годам лишения свободы. Приговор вызвал волну протестов и давление со стороны различных армянских организаций, которые требовали от Югославии освобождения двух приговоренных лиц. В итоге, спустя несколько лет проведенных в заключении, они были амнистированы указом Президиума СФРЮ и депортированы из Югославии. Этот конкретный пример дал автору повод сделать более широкие выводы о проблеме терроризма в современном мире. Пока существуют разные политические интересы, до тех пор будут существовать и различные взгляды на индивидуальный террор - для одних это легитимная борьба (национальная или классовая), для других - это недопустимое насилие и зло в своей сущности.

КЛЮЧЕВЫЕ СЛОВА: международный терроризм, Холодная война, полувоенные организации, Армяне, Югославия, Турция 